\title{
Evaluation of Heavy Metal in Soils From Enyimba Dumpsite in Aba, Southeastern Nigeria Using Contamination Factor and Geo-Accumulation Index
}

\author{
Amadi Akobundu N. ${ }^{1}$ \& Nwankwoala H. O. ${ }^{2}$ \\ ${ }^{1}$ Department of Geology, Federal University of Technology, Minna, Nigeria \\ ${ }^{2}$ Department of Geology, University of Port Harcourt, Port Harcourt, Nigeria \\ Correspondence: Nwankwoala H. O., Department of Geology, University of Port Harcourt, Port Harcourt, \\ Nigeria. E-mail: nwankwoala_ho@yahoo.com
}

\author{
Received: November 27, 2012 Accepted: March 27, 2013 Online Published: April 11, 2013 \\ doi: $10.5539 /$ eer.v3n1p 125 \\ URL: http://dx.doi.org/10.5539/eer.v3n1p125
}

\begin{abstract}
The manner in which municipal wastes generated are disposed in most urban areas in Nigeria is worrisome. The upsurge in population density and its resultant increase in urbanization and industrialization and the amount of waste generated in Aba, are of great concern. The objective of this research is to evaluate the concentration of some heavy metals in soils in the vicinity of Enyimba dumpsite in Aba, Nigeria. Thirty soil samples were collected and analyzed in the laboratory for some heavy metals by atomic absorption spectrophotometric method and multivariate statistical techniques. Twenty-five of the samples were obtained from the vicinity of the dumpsite while five samples are collected far away from the dumpsite to serve as control samples. The overall decreasing metal concentration in the dumpsite soil is: $\mathrm{Cd}>\mathrm{Co}>\mathrm{Cu}>\mathrm{Zn}>\mathrm{As}>\mathrm{Pb}>\mathrm{Mn}>\mathrm{Ni}>\mathrm{Cr}$. A positive correlation exists between $\mathrm{Cd}$ and organic matter $(\mathrm{r}=0.598)$. Geo-accumulation index and contamination factor showed a moderate contaminated with $\mathrm{Cd}$ only while the other metals are in their uncontaminated level. Factor analysis revealed four major components accounting for $78.82 \%$ of cumulative variance of the contamination: $\mathrm{Cd}, \mathrm{Cu}, \mathrm{Co}$ and organic matter; $\mathrm{Pb}, \mathrm{Zn}$ and $\mathrm{pH} ; \mathrm{Mn}, \mathrm{As}$, clay + silt and finally $\mathrm{Cr}$ and $\mathrm{Ni}$. From the above observations, it is evident that only $\mathrm{Cd}$ showed more pronounced level of pollution than any other metal. The need to replace open dumpsites with well designed sanitary landfills is advocated.
\end{abstract}

Keywords: heavy metals, contamination, dumpsite, analysis and Aba

\section{Introduction}

Open dumps are the oldest and most common way of disposing of solid wastes. The practice of landfill as a method of waste disposal in many developing countries is far from standard recommendations (Mull, 2005; Adewole, 2009). Solid and fluid wastes generation and their poor disposal mechanism in the urban areas of most developing countries have become a threat to the environment (Amadi et al., 2010). Rapid rural-urban migration and upsurge in population of many African, Asian and South American countries have also intensified and contributed their quota to the pollution hazards on and in the environment (Awomeso et al., 2010). Inadequate information and technology as well as insufficient resources and poor policy execution capacity are some of the causes of environmental pollution arising from municipal waste in most state capital in Nigeria. According to Amadi et al. (2010), dumpsites in most developing countries are usually unlined shallow hollow excavations arising from abandoned burrow-pits and quarry-sites without any environmental impact assessment studies.

Many cities in Nigeria have developed without proper planning and it has led to the presence of open dumps within built-up areas inhabited by millions of people. Consequently, such waste dumps become point source for soil pollution as they serve as host for leachate from dumpsites. The composition of solid wastes in major cities in Nigeria comprises domestic garbage, wood, agricultural waste, industrial waste, hospital waste, polythene bags, plastics, broken glasses, abandoned automobiles, demolition waste, ash, dust, human and animal waste. Solid waste are materials discarded after it has served its purpose or is no longer useful while industrial solid waste are usually by-product or end-product of materials from large-scale production factories and industries (Awomeso et al., 2010). 
Due to the high cost of fertilizer, it is now a common practice for farmers to search for soils rich in organic manure. Such soils are easily obtained from dumpsites and used for planting of vegetables and food crops. Ademoroti (1990) ascertained that there is a positive linear correlation between heavy metals $(\mathrm{Cd}, \mathrm{Pb}$, and $\mathrm{Ni})$ in the soil and vegetables grown on it. It has also been established that heavy metals have a high affinity for organic matter and clay soils (Bodur \& Ergin, 1994; Zonta et al., 1994). The aim of this study was to examine the extent of heavy metal contamination in soils within Enyimba dumpsite. It also attempts to ascertain the suitability of such soils for agricultural purposes.

\section{Materials and Methods}

\subsection{Study Area Description}

Enyimba dumpsite is located in Aba, the commercial and industrial nerve centre of Southern Nigeria. The high number of markets, industries and fabricating companies in the area has resulted to high population density and high accumulation of wastes (Figure 1). Enyimba dumpsite lies between latitudes $05^{\circ} 06.796^{\prime} \mathrm{N}$ and $05^{\circ} 06.948^{\prime} \mathrm{N}$ and Longitudes $07^{\circ} 19.604^{\prime} \mathrm{E}$ and $07^{\circ} 19.758^{\prime} \mathrm{E}$. The burrow-pits excavated during the construction of the Aba-Port-Harcourt expressway gave rise to Enyimba dumpsite. It is an open dumpsite and its proximity to markets and industries in Aba gives it high patronage. The heavy anthropogenic activities and the corresponding huge amount of wastes generated and discarded (Figure 1) on daily basis lead to the choice of Enyimba dumpsite for this study. Scavengers, birds, rodents, reptiles and micro-organisms abound in the decaying portions of the dump. The area is a low land and is drained by Imo and Aba Rivers and their tributaries (Figure 2). The area has two distinct seasons: a dry season which lasts from November to March, and a rainy season which starts from April to October. Rainfall is brought by the moist Equatorial Maritime Air Mass from the Gulf of Guinea with prevailing winds from the south to west. The average annual rainfall is about $2500 \mathrm{~mm}$ (Uma, 1990).

\subsection{Geology and Hydrogeology}

The study area is underlain by the Benin Formation which consists of unconsolidated, dominantly sandy formations also known as the coastal plain-sand of Miocene to Recent age (Uma, 1990). The formation is made up of very friable sands while clays occurring as streak and discontinuous lenses (Figure 2). Generally the sands are fine grained to coarse grained and are poorly sorted with pebble beds occurring in lenses (Onyeagocha, 1980). The studied area is underlain by a thick unconfined aquifer of regional extent. Lenticular clays and shales confine high yielding aquifers. Most of the boreholes tap unconfined aquifers which are regional in extent but comes in contact with Ogwashi-Asaba Formation and Alluvium in the north and south respectively (Figure 2).

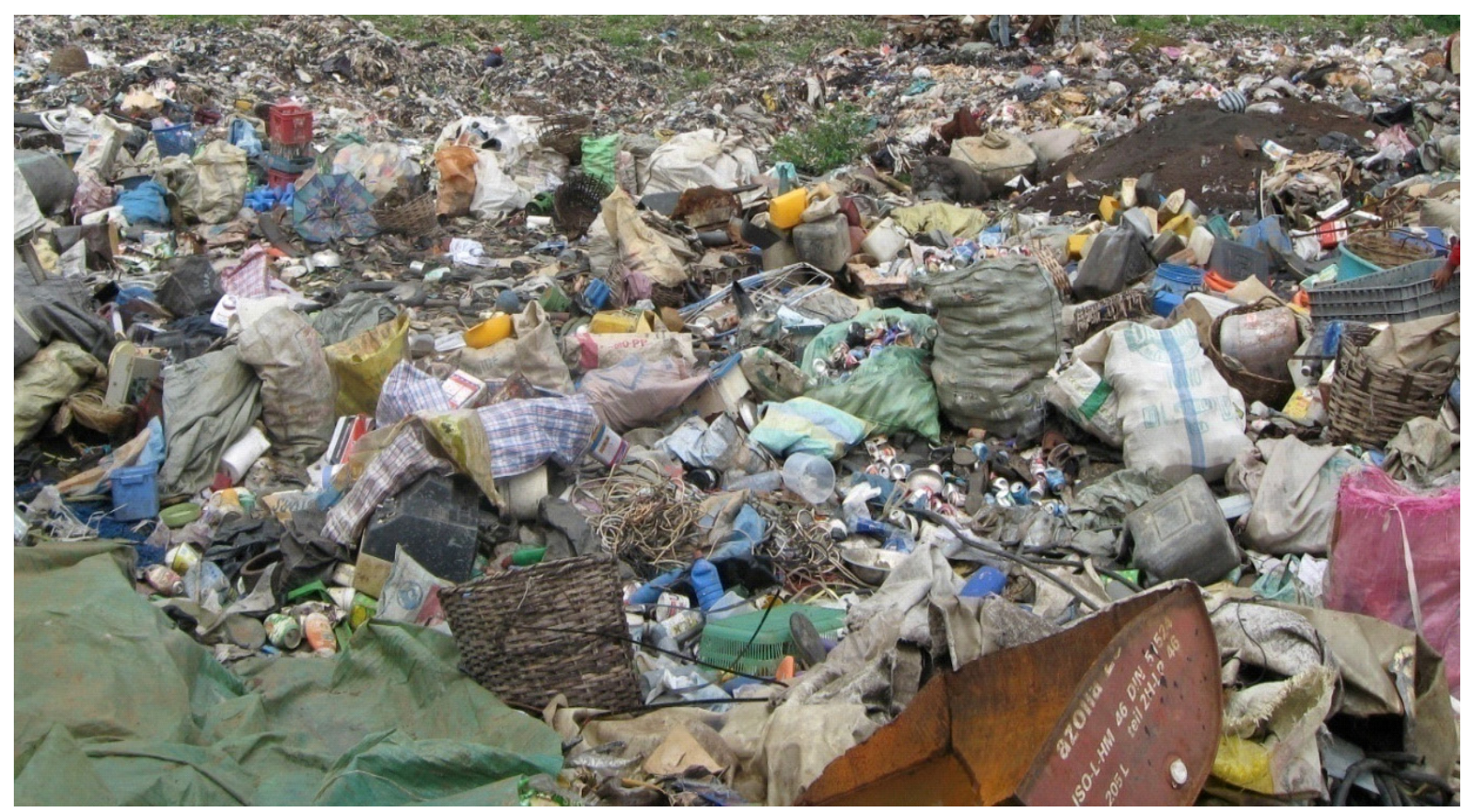

Figure 1. An overview of Enyimba dumpsite (Source: Amadi, 2011) 

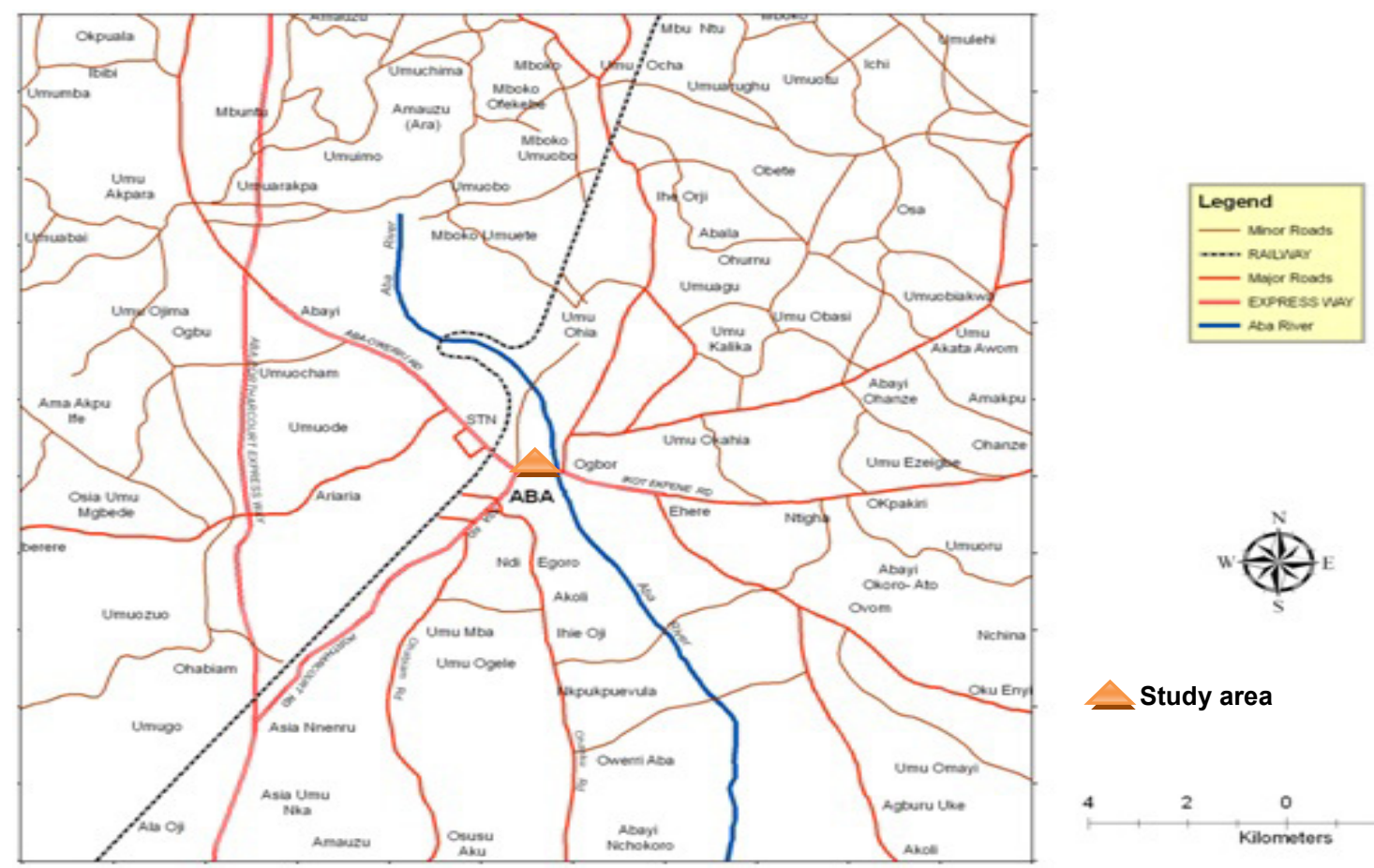

Figure 2. Location map of the study area (Source: Amadi, 2011)

\subsection{Soil Sampling}

A total of thirty soil samples were used for the present study. Twenty-five samples were collected within the vicinity of the dumpsite while five samples were collected far away from the dumpsite, which serves as control samples. Six samples were collected consecutively every month for five months, during the dry season, from November, 2007 to March, 2008. Samples collected were stored in sealed polythene bags and transported to the laboratory for pre-treatment and analyses.

\subsection{Laboratory Analyses}

The soil samples were air-dried, mechanically grounded using a stainless steel roller and sieved to obtain $<2$ $\mathrm{mm}$ fraction. A $30 \mathrm{~g}$ sub-sample was taken from the original bulk soil of $<2 \mathrm{~mm}$ fraction and regrounded to obtain $<200 \mu \mathrm{m}$ fraction using a mortar and pestle. This fine material was used to determine organic carbon and total metal content in soil. The $<2 \mathrm{~mm}$ fraction was used to determine $\mathrm{pH}(1: 5)$ soil/water extract and particle size analysis using Rayment and Higginson (1992) method. Organic carbon was determined by the modified Walkley and Black method by Saharawat (1982).

Soil samples were digested in a mixture of concentrated nitric acid $\left(\mathrm{HNO}_{3}\right)$, concentrated hydrochloric acid $(\mathrm{HCl})$ and $27.5 \%$ hydrogen peroxide $\left(\mathrm{H}_{2} \mathrm{O}_{2}\right)$ according to the USEPA method 3050B for the analysis of heavy metals (USEPA, 1996). A reagent blank was run for the set of six samples. The extracts were analyzed by atomic absorption spectrophotometer (Perkin Elmer, Model No. 2380).

\subsection{Statistical Analysis}

In order to quantitatively analyze and confirm the relationship among soil properties $(\mathrm{pH}$, organic matter, clay and silt) and heavy metal content, Pearson correlation analysis was applied to the dataset. Principal component analysis (PCA) was adopted to assist the interpretation of elemental data. PCA was used in identifying the different groups of metals that correlate and thus can be considered as having a similar behavior and common source (Tahri et al., 2005). A component with an eigenvalues of less than one is considered less important and such an observed variable can be ignored (Baptista et al., 2007). All the statistical analyses were performed using SPSS for windows (release ver.11, Inc., Chicago, IL).

\subsection{Data Analysis}

Contamination factor (CF) and geo-accumulation index (Geol) are quantitative check used to describe concentration trend of metals in soils. Contamination factor (CF) is a quantifier of the degree of contamination 
relative to either the average crustal composition of the respective metal or to measured background values from geologically similar and uncontaminated area (Tijani et al., 2004). It is expressed as:

$$
C F=C_{m} / B_{m}
$$

Where $\mathrm{C}_{\mathrm{m}}$ is the mean concentration of metal $\mathrm{m}$ in soil and $\mathrm{B}_{\mathrm{m}}$ is the background concentration (value) of metal $\mathrm{m}$, either taken from the literature (average crustal abundance) or directly determined from a geologically similar material.

Geo-accumulation index (GeoI) as proposed by Mueller (1979) and cited by Lokeshwari and Chandrappa (2006) have been widely used to evaluate the degree of heavy metal contamination in terrestrial and aquatic environments as expressed:

$$
G e o I=\ln \left[C_{m} / 1.5^{*} B_{m}\right)
$$

Where $\mathrm{C}_{\mathrm{m}}$ and $\mathrm{B}_{\mathrm{m}}$ are as defined above, while 1.5 is a factor for possible variation in the background concentration due to lithologic differences. GeoI is classified into seven descriptive classes as follows: $<0=$ practically uncontaminated; $0-1$ uncontaminated to slightly contaminated, $2-3=$ moderately to highly contaminated, $4-5=$ highly to very strongly contaminated, $>5=$ very strongly contaminated. The latter is an open-end class that is indicative of all values greater than 5, and a GeoI of 6 is said to be indicative of 100 -fold enrichment of a metal with respect to the baseline value (Mueller, 1979).

\section{Results}

The statistical summary of the analyzed heavy metals are contained in Table 1 while their respective mean concentration are displayed in Figure 3. The determined concentrations of contamination factor and geo-accumulation index of metals in dumpsite soil are shown in Table 2. Also, the results of correlation analysis and principal component analysis are summarized in Tables 3 and 4 respectively.

Table 1. Statistical summary of Heavy Metals concentration in $(\mathrm{mg} / \mathrm{kg})$

\begin{tabular}{llll}
\hline Parameters & Minimum & Maximum & Mean \\
\hline $\mathrm{Cd}$ & 0.18 & 2.60 & 1.40 \\
$\mathrm{Mn}$ & 0.30 & 48.10 & 28.50 \\
$\mathrm{Cu}$ & 1.06 & 15.98 & 12.86 \\
$\mathrm{Cr}$ & 0.02 & 2.78 & 1.34 \\
$\mathrm{Ni}$ & 0.50 & 6.25 & 2.94 \\
$\mathrm{~Pb}$ & 0.24 & 2.15 & 1.08 \\
$\mathrm{As}$ & 0.01 & 0.08 & 0.05 \\
$\mathrm{Zn}$ & 2.40 & 28.50 & 16.04 \\
$\mathrm{Co}$ & 0.20 & 17.90 & 10.58 \\
$\mathrm{pH}$ & 4.80 & 6.90 & 5.70 \\
\hline
\end{tabular}

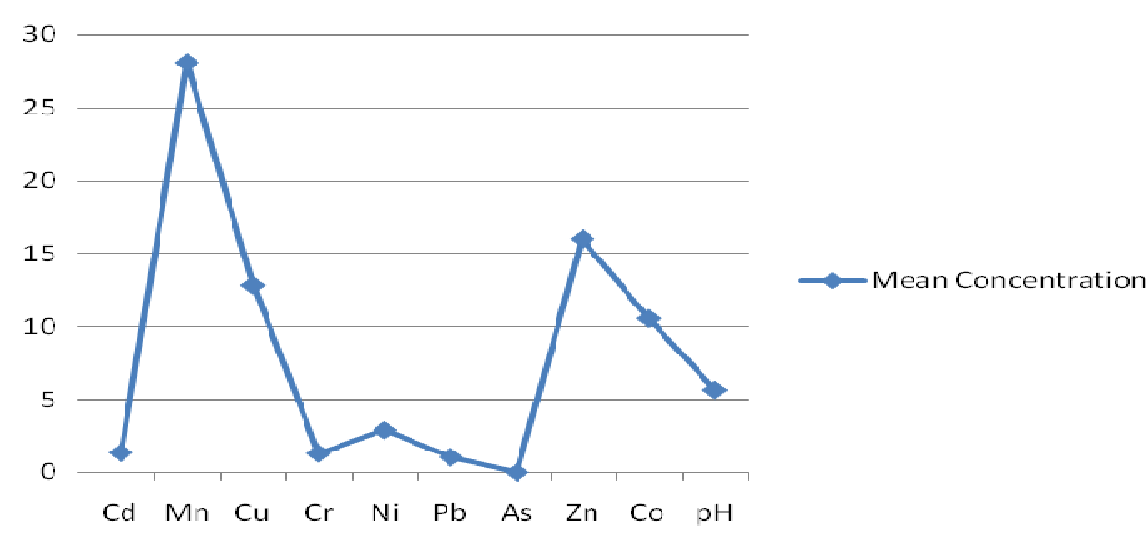

Figure 3. Mean concentration of heavy metals from Eyimba dumpsite, Aba 
Table 2. Metal contamination factor and geo-accumulation index of metals in soil from the dumpsite

\begin{tabular}{llllll}
\hline Parameters & $\mathrm{C}_{\mathrm{m}}$ & $\mathrm{B}_{\mathrm{m}}$ & $\mathrm{CF}$ & GeoI & Overall summary of contamination level \\
\hline $\mathrm{Cd}$ & 1.40 & 0.15 & 9.33 & 1.828 & Moderately contaminated \\
$\mathrm{Mn}$ & 48.12 & 1000 & 0.048 & -3.442 & Uncontaminated \\
$\mathrm{Cu}$ & 12.86 & 70 & 0.184 & 1.098 & Slightly contaminated \\
$\mathrm{Cr}$ & 1.34 & 122 & 0.011 & -4.920 & Uncontaminated \\
$\mathrm{Ni}$ & 2.94 & 80 & 0.037 & -3.709 & Uncontaminated \\
$\mathrm{Pb}$ & 1.08 & 16 & 0.068 & -3.101 & Uncontaminated \\
$\mathrm{As}$ & 0.05 & 5 & 0.010 & -3.007 & Uncontaminated \\
$\mathrm{Zn}$ & 16.04 & 132 & 0.122 & -2.513 & Uncontaminated \\
$\mathrm{Co}$ & 10.58 & 23 & 0.460 & -1.181 & Uncontaminated \\
\hline
\end{tabular}

CF- contamination factor; GeoI- geo-accumulation index;

$\mathrm{C}_{\mathrm{m}}$ - mean concentration of the metal in the soil;

$B_{m}$ - average crustal abundance (background value) in an uncontaminated soil, adopted from (Dineley et al., 1976).

Table 3. Pearson correlation coefficient matrix for heavy metals in soils from the dumpsite

\begin{tabular}{clllllllllllr}
\hline & $\mathrm{Cd}$ & $\mathrm{Mn}$ & $\mathrm{Cu}$ & $\mathrm{Cr}$ & $\mathrm{Ni}$ & $\mathrm{Pb}$ & $\mathrm{Ar}$ & $\mathrm{Zn}$ & $\mathrm{Co}$ & $\mathrm{pH}$ & $\mathrm{OM}$ & $\mathrm{C}+\mathrm{S}$ \\
\hline $\mathrm{Cd}$ & 1.000 & & & & & & & & & & \\
$\mathrm{Mn}$ & 0.109 & 1.000 & & & & & & & & & \\
$\mathrm{Cu}$ & 0.065 & -0.112 & 1.000 & & & & & & & & \\
$\mathrm{Cr}$ & 0.252 & 0.041 & 0.141 & 1.000 & & & & & & & \\
$\mathrm{Ni}$ & 0.354 & $0.678^{* *}$ & 0.101 & 0.093 & 1.000 & & & & & & \\
$\mathrm{~Pb}$ & 0.327 & -0.113 & $0.818^{* *}$ & 0.008 & 0.334 & 1.000 & & & & & \\
$\mathrm{As}$ & 0.080 & 0.199 & 0.249 & 0.118 & -0.333 & 0.090 & 1.000 & & & & \\
$\mathrm{Zn}$ & 0.153 & 0.205 & $0.788^{* *}$ & -0.044 & $0.534^{*}$ & $0.637^{* *}$ & 0.110 & 1.000 & & & \\
$\mathrm{Co}$ & $0.433^{*}$ & 0.084 & 0.211 & 0.208 & $0.360^{*}$ & 0.016 & 0.186 & 0.127 & 1.000 & & \\
$\mathrm{pH}$ & 0.106 & -0.112 & 0.024 & 0.091 & 0.119 & 0.095 & 0.112 & 0.085 & 0.101 & 1.000 & \\
$\mathrm{OM}$ & $0.598^{*}$ & $0.724^{* *}$ & 0.028 & 0.284 & 0.284 & 0.195 & 0.220 & 0.054 & 0.066 & $0.841^{*}$ & 1.000 & \\
$\mathrm{C}+\mathrm{S}$ & 0.045 & 0.293 & 0.123 & 0.031 & -0.023 & $0.545^{*}$ & 0.151 & 0.049 & 0.137 & 0.521 & -0.192 & 1.000 \\
\hline **: Correlation is significant at the 0.01 level (2-tailed); *: Correlation is significant at the 0.05 level (2-tailed); \\
OM: Organic Matter; C S: Clay + Silt.
\end{tabular}


Table 4. Varimax normalized rotated principal component loading of selected metals and soil components

\begin{tabular}{lllll}
\hline Variables & PC-1 & PC-2 & PC-3 & PC-4 \\
\hline $\mathrm{Cd}$ & $\mathbf{0 . 8 0 9}$ & 0.320 & 0.056 & -0.207 \\
$\mathrm{Mn}$ & -0.072 & -0.027 & $\mathbf{0 . 8 5 8}$ & 0.204 \\
$\mathrm{Cu}$ & $\mathbf{0 . 6 0 5}$ & 0.341 & -0.074 & 0.082 \\
$\mathrm{Cr}$ & -0.340 & 0.178 & 0.151 & $\mathbf{0 . 5 0 2}$ \\
$\mathrm{Ni}$ & 0.123 & 0.109 & -0.148 & $\mathbf{0 . 6 1 3}$ \\
$\mathrm{Pb}$ & 0.310 & $\mathbf{0 . 6 3 3}$ & -0.117 & -0.020 \\
$\mathrm{As}$ & -0.134 & 0.029 & $\mathbf{0 . 5 8 0}$ & 0.231 \\
$\mathrm{Zn}$ & 0.228 & $\mathbf{0 . 7 3 4}$ & 0.163 & 0.530 \\
$\mathrm{Co}$ & $\mathbf{0 . 7 3 5}$ & -0.423 & -0.193 & 0.745 \\
$\mathrm{pH}$ & 0.159 & $\mathbf{0 . 6 3 1}$ & 0.072 & 0.231 \\
Organic Matter & $\mathbf{0 . 7 2 0}$ & -0.193 & -0.088 & -0.195 \\
Clay + Silt & -0.203 & -0.145 & $\mathbf{0 . 8 6 5}$ & 0.136 \\
Eigenvalue & 4.142 & 3.078 & 2.641 & 1.705 \\
Total Variance (\%) & 26.356 & 20.321 & 17.785 & 14.354 \\
Cumulative \% & 26.356 & 46.677 & 64.462 & 78.816 \\
\hline
\end{tabular}

\section{Discussion}

The fieldwork was done during the dry season in order to obtain maximal heavy metal concentration from the soil. Yahaya (2009) confirmed that the concentration of heavy metal in soil is higher in dry season than in rainy season because more heavy metals are lost in the soil due to run-off and infiltration in rainy season which are absent in dry season. The concentration of cadmium ranges from $0.18-2.60 \mathrm{mg} / \mathrm{kg}$ with a mean concentration of $1.40 \mathrm{mg} / \mathrm{kg}$ (Table 1). The values of Cd obtained in this study are higher than the average crustal abundance of $0.15 \mathrm{ppm}$ in an uncontaminated soil. The calculated geo-accumulation index (Geol) for cadmium indicates that the soils around the dumpsite are moderately contaminated (Table 2) and Cd showed moderately positive correlation with Cobalt and organic matter ( 0.05 level).

Cadmium metal is used as an anticorrosive, electroplated on steel, Cadmium sulfide and selenide are commonly used as pigments in plastics, batteries and in various electronic components. It is also used with inorganic fertilizers produced from phosphate ores and when these products are no more servisable, they are thrown into the dump as waste. During decomposition, the Cd component is leached into the surrounding soil and over time gets accumulated in the soil. Cadmium is extremely toxic and the primary use of soil high in Cd in form of manure for the cultivation of vegetables and other food crops could cause adverse health effect to consumers such as renal disease and cancer (Che et al., 2003; Gorenc et al., 2004). Moreover, when ingested by humans, cadmium accumulates in the intestine, liver and kidney and chronic exposure of $\mathrm{Cd}$ causes proximal tubular disease and osteomalacia (Pascual et al., 2004). Therefore, the soils from this dumpsite are not suitable for agricultural purposes.

Manganese ranged $0.30-92.10 \mathrm{mg} / \mathrm{kg}$. The mean was $48.12 \mathrm{mg} / \mathrm{kg}$. Abbasi et al. (1998) gave an accepted value of $1000 \mathrm{mg} / \mathrm{kg}$ for manganese in an uncontaminated soil and the calculated GeoI value gave a value that indicates uncontaminated. Manganese is essential for plants and animals. Manganese dioxide and other manganese compounds are used in products such as batteries, glass and fireworks (Huang \& Lin, 2003; Aboud \& Nandini, 2009). Potassium permanganate is used as an oxidant for cleaning, bleaching and disinfection purposes. Other manganese compounds are used in fertilizer, fungicides and as livestock feeding supplements. It can be adsorbed onto soil depending on organic content, $\mathrm{pH}$, grain-size and cation exchange capacity (CEC) of the soil and this can be exemplified by the strong positive correlation (Table 3$)$ with organic matter $(<0.01$ level).

Concentration in copper varied from $1.06-15.98 \mathrm{mg} / \mathrm{kg}$ with an average value of $12.86 \mathrm{mg} / \mathrm{kg}$. A moderately high positive correlation with lead and Zinc was established $(<0.01$ level). Copper is widely used in electrical wiring, roofing, various alloys, pigments, cooking utensils, piping and in the chemical industries (Aboud \& Nandini, 2009). Copper compounds are used in fungicides, algicides, insecticides, wood preservation, 
electroplating, dye manufacture, engraving, lithography, petroleum refining and pyrotechnics. It is also added to fertilizers and animal feeds as a nutrient to support plant and animal growth (Mielke et al., 1991; Pascual et al., 2004). The $\mathrm{Cu}$ concentration in GeoI is within the uncontaminated level.

Chromium concentration ranges from $0.02-2.78 \mathrm{mg} / \mathrm{kg}$ with a mean value of $1.34 \mathrm{mg} / \mathrm{kg}$. No correlation was found with other metals and its concentration falls within the uncontaminated. It is used in alloys, electroplating, pigments, paints manufacture, fungicides, photography, glass and leather tanning industries. Chromium is carcinogenic by inhalation and corrosive to tissue (Lin et al., 2002; Aboud \& Nandini, 2009).

Nickel measured concentrations are below the average crustal abundance in an uncontaminated soil. A moderate positive correlation with $\mathrm{Zn}$ was noted at $<0.05$ level (Table 3). Nickel is used mainly as alloys, which are characterized by their hardness, strength, and resistance to corrosion and heat. It is a major component in the production of stainless steels, non-ferrous alloys and super alloys. Other application of Ni includes electroplating, as catalysts, in nickel-cadmium batteries, coins, welding and electronic products (Pascual et al., 2004; Amadi, 2011).

The results show that lead concentration deposited at the dumpsite ranged $0.24-2.15 \mathrm{mg} / \mathrm{kg}$ with a mean concentration of $1.08 \mathrm{mg} / \mathrm{kg}$ (Table 1). Though there was an observed strong correlation with $\mathrm{Cu}(<0.01$ level), its concentration is within the level of uncontaminated soil. Lead is non essential for plants and animals and is toxic by ingestion-being a cumulative poison (MacFarlane \& Burchett, 2002; Sharma \& Pervez, 2003). Lead toxicity leads to anaemia both by impairment of haemo-biosynthesis and acceleration of red blood cell destruction. In addition, $\mathrm{Pb}$ reduces sperm count, damages kidney, liver, blood vessels, nervous system and other tissues in human (Anglin-Brown et al., 1995). Other uses of lead is in the production of lead acid batteries, solder, alloys, cable sheathing, pigments, ammunition, glass and plastic stabilizers. Tetraethyl and tetramethyl lead are important due to their extensive use as antiknock compounds in petrol (Mielke et al., 1991; McAllister et al., 2005).

Arsenic concentration varied between $0.01 \mathrm{mg} / \mathrm{kg}$ and $0.08 \mathrm{mg} / \mathrm{kg}$ with an average concentration of $0.05 \mathrm{mg} / \mathrm{kg}$. These values are found to be low the critical value of $16 \mathrm{mg} / \mathrm{kg}$ (average crustal abundance) for an uncontaminated soil (Table 2). The GeoI concentration lies below the range for uncontaminated soil. Arsenic is highly carcinogenic has no nutritional value for plant and animal (Amadi et al., 2010).

Zinc in the study ranged $2.40-28.50 \mathrm{mg} / \mathrm{kg}$. The mean value was $16.04 \mathrm{mg} / \mathrm{kg}$. With this values, the concentration of $\mathrm{Zn}$ in soils from the dumpsite are within the stipulated guideline limits (Table 2). Zinc had very strong positive correlation with $\mathrm{Cu}$ and $\mathrm{Pb}(<0.01$ level) and moderately positive correlation with $\mathrm{Ni}(<0.05$ level). It is an essential growth element for plants and animals but can be toxic at elevated concentration. Zinc is used in making alloys of brass and bronze, batteries, fungicides, pigments, pesticides, galvanizing steel and iron products. It is used in combination with some enzymes system which contributes to energy metabolism, transcription and translation (Anglin-Brown et al., 1995). Excessive concentration of $\mathrm{Zn}$ in soil leads to phyto-toxicity as it is a weed killer (Preda \& Cox, 2002; Aboud \& Nandini, 2009).

Cobalt concentration ranged $0.20-17.90 \mathrm{mg} / \mathrm{kg}$ with a mean value of $10.57 \mathrm{mg} / \mathrm{kg}$. The measured concentrations of Co are acceptable range for an uncontaminated soil (Table 2). Cobalt is widely used as alloys for steels, electroplating, fertilizer, porcelain and glass making. It is essential for the growth of algae and bacteria but required in trace concentration for higher plants and animals (Mielke et al., 1991; Rayment \& Higginson, 1992; Aboud \& Nandini, 2009; Amadi et al., 2012).

Among significant variables that control the distribution and enrichment of heavy metals in soils are $\mathrm{pH}$ of soil, grain size of the soil, amount of organic matter in the soil and the cation exchange capacity of the soil (Lin et al., 2002; Huang \& Lin, 2003). The soil pH is generally low, signifying acidic soil while loamy soil characterize the top soil at the dumpsite and these condition enhances the precipitation and bio-accumulation of heavy metals in soil (Ujevic et al., 2000). Heavy metals have a strong affinity for organic content, clay and silt fraction because of their high cation exchange capacity (Bodur \& Ergin, 1994; Zonta et al., 1994). The top-soil from the dumpsite comprises of organic content, clay and silt fraction. This agrees with the result of geophysical investigation carried out earlier which suggest the presence leachate near the top-soil (Amadi et al., 2010)

Four principal components (Eigenvalues $>1$ ) emerged accounting for $78.82 \%$ of cumulative variance from the principal component analysis (Table 4). The first principal component (PC-1) loading with 26.36\% variance showed higher loading for $\mathrm{Cd}, \mathrm{Cu}, \mathrm{Co}$ and organic matter. Human activities in the area involving electrical wiring, various alloys, alloys, pigments, fungicides, insecticides, electroplating, cooking utensils, batteries and dye production are the possible sources of $\mathrm{Cd}, \mathrm{Cu}$ and $\mathrm{Co}$. When these products are thrown into the dumpsite, 
these elements are leached away and accumulate at the top soil where they are adsorbed because of affinity for metals by organic matter (Rayment \& Higginson, 1992; Odero et al., 2000; Amadi, 2011).

The second principal component (PC-2) has loading $20.32 \%$ of total variance, had high loading for $\mathrm{Pb}, \mathrm{Zn}$ and $\mathrm{pH}$. These might be due to soldering, battery charging, zinc-roofing sheet, electroplating cable sheathing, pigments, ammunition, glass and plastic stabilizers, artisanal activities going on in this area. $\mathrm{Pb}$ and $\mathrm{Zn}$ are essential components of the raw material used in soldering wires and lead accumulators (Odero et al., 2000; Banar et al., 2006). The $\mathrm{pH}$ of the soil could have contributed to $\mathrm{Pb}$ and $\mathrm{Zn}$ retention in the soil, resulting in low mobility of the metals (Alloway, 1990; Yoshida et al., 2002; Amadi et al., 2012).

The third principal component (PC-3) explains $17.79 \%$ of the total variance and comprises of $\mathrm{Mn}$, As and clay plus silt. Industrial activities domiciled in the area may be responsible for the presence of $\mathrm{Mn}$ and As while the physico-chemical properties of clay could have encouraged their availability in the soil. The fourth principal component (PC-4) has a moderate loading for $\mathrm{Cr}$ and $\mathrm{Ni}$ which accounts for $14.35 \%$ of the total variance. This could be attributed to domestic waste discharged at the dumpsite and the decomposition of vehicle and machine scraps (Pereira et al., 2007). The dumping of unwanted portion of paints, fungicides, photographic films, glass and waste from leather tanning industries can also enrich the soil with $\mathrm{Cr}$ and Ni. The concentrations of heavy metals in the control samples are negligible, typical of an uncontaminated soil and this further confirmed that the dumpsite is a possible source of heavy metals in the soil.

\section{Conclusion}

In this study, contamination factor, geo-accumulation index, correlation and principal component analysis were used for determining the environmental quality of soils from dumpsite in terms of heavy metal accumulation and other soil properties. The result revealed the following trend in their order of geo-accumulation in the soil: $\mathrm{Cd}>$ $\mathrm{Co}>\mathrm{Cu}>\mathrm{Zn}>\mathrm{As}>\mathrm{Pb}>\mathrm{Mn}>\mathrm{Ni}>\mathrm{Cr}$. There is a very strong correlation between organic matter content on cadmium and copper metal accumulation, suggesting that the soil around the dumpsite are moderately and slightly contaminated with cadmium and copper respectively. Contamination factor and geo-accumulation index further confirmed that the soil from the dumpsite was moderately contaminated with $\mathrm{Cd}$, slightly contaminated with $\mathrm{Cu}$ and presently uncontaminated with $\mathrm{Co}, \mathrm{Zn}, \mathrm{As}, \mathrm{Pb}, \mathrm{Mn}, \mathrm{Ni}$ and $\mathrm{Cr}$. The principal component analysis summarizes (reduces) the dataset into four major components representing four possible different sources of the elements. The effectiveness of multivariate statistical analysis in evaluating heavy metal concentration in dumpsite soils has been demonstrated in this study.

\section{Recommendation}

A well designed sanitary landfill that incorporates the local geology, prevalent climatic condition, slope geometry, type of waste generated, nature of settlement and cultural believe of the people that will mitigate (impede) the infiltration of the leachate into the soil and shallow groundwater system are advocated. The use of Enyimba dumpsite should be discontinued. Although no severe pollution may have occurred at present apart from cadmium, the continuous dumping of waste at the dumpsite may lead to the enrichment of the soil with other metals that are presently at uncontaminated levels. Therefore, separation and recycling of wastes as well as the use of sanitary landfills and incinerators should be encouraged. Due to the toxicity of heavy metals, the use of manure from the dumpsite for agricultural purposes should be discouraged as plants and vegetables can easily absorb them.

\section{Acknowledgement}

The researchers acknowledge their mentor, Prof P. I. Olasehinde, Department of Geology Department, Federal University of Technology, Minna, Nigeria for his support and encouragement.

\section{References}

Abbasi, S. A., Abbasi, N., \& Soni, R. (1998). Heavy metals in the environment (1st ed., p. 314). Mittal Publ.

Aboud, S. J., \& Nandini, N. (2009). Heavy metal analysis and sediment quality values in urban lakes. Am. J. Environ. Sci., 5(6), 678-687.

Ademoroti, C. M. A. (1990). Bio-accumulation of heavy metals in some Mangrove Fauna and Flora. In Environmental chemistry and toxicological consultancy, Benni, 180-182.

Adewole, A. T. (2009). Waste management towards sustainable development in Nigeria: A case study of Lagos State. Int. NGO J., 4(4), 173-179.

Alloway, B. J. (1990). Heavy metals in soil (p. 339). New York: John Wiley and sons Inc. 
Amadi, A. N. (2010). Effects of urbanization on groundwater quality: A case study of Port-Harcourt, Southern Nigeria. Natur. Appl. Sci. J., 11(2), 143-152.

Amadi, A. N. (2011). Assessing the Effects of Aladimma Dumpsite on Soil and Groundwater Using Water Quality Index and Factor Analysis. Australian Journal of Basic and Applied Sciences, 5(11), 763-770.

Amadi, A. N., Ameh, M. I., \& Jisa, J. (2010). The impact of dumpsites on groundwater quality in Markurdi Metropolis, Benue State. Natur. Appl. Sci. J., 11(1), 90-102.

Amadi, A. N., Olasehinde, P. I., Okosun, E. A., Okoye, N. O., Okunlola, I. A., Alkali, Y. B., \& Dan-Hassan, M. A. (2012). A Comparative Study on the Impact of Avu and Ihie Dumpsites on Soil Quality in Southeastern Nigeria. American Journal of Chemistry, 2(1), 17-23.

Anglin-Brown, B., Armour, A., \& Lalor, G. C. (1995). Heavy metal pollution in Jamaica 1: Survey of cadmium, lead and zinc concentrations in the Kintyre and Hope flat district. Environ. Geochem. Health, 17, 51-56.

Awomeso, J. A., Taiwo, A. M., Gbadebo, A. M., \& Arimoro, A. O. (2010). Waste disposal and pollution management in urban areas: A workabale remedy for the environment in developing countries. Am. $J$. Environ. Sci., 6(1), 26-32.

Banar, M., Aysun, O., \& Mine, K. (2006). Characterization of the leachate in an urban landfill by physicochemical analysis and solid phase microextraction. GC/MS. Environ. Monitor. Assess., 121, 439-459.

Baptista, N. J. A., Smith, B. J., \& McAllister, J. J. (2007). Concentration of heavy metals in sediments from urban runoff: implications for environmental quality emNitero'I / RJ-Brazil. An acad. Bras Cienc., 79, 981-995.

Bodur, M. N., \& Ergin, M. (1994). Geochemical characteristics of the recent sediment from the Sea of Marmara. Chem. Geol., 115, 73-101. http://dx.doi.org/10.1016/0009-2541(94)90146-5

Che, Y. Q., \& Lin, W. Q. (2003). The distributions of particulate heavy metals and its indication to the transfer of sediments in the Changiiang estuary and Hangzhou Bay. Mar. pollut. Bull., 46, 123-131. http://dx.doi.org/10.1016/S0025-326X(02)00355-7

Dineley, D., Hawkes, D., Hancock, P., \& Williams, B. (1976). Earth resources - a dictionary of terms and concepts (p. 205). London: Arrow Books Ltd.

Gorenc, S., Kostaschuk, R., \& Chen, Z. (2004). Spatial variation in heavy metals on tidal flats in the Yangtze Estuary China. Environ. Geo., 45, 1101-1108.

Huang, K., \& Lin, S. (2003). Consequences and implication of heavy metal spatial in sediments of Keelung River drainage basin, Taiwan. Chemosp., 53, 1113-1121.

Lin, Y. P., Teng, T. P., \& Chang, T. K. (2002). Multivariate analysis of soil heavy metal pollution and landscape in Changhua Country in Taiwan. Landscape Urban Plan., 62, 19-35. http://dx.doi.org/10.1016/S0169-2046(02000094-4

Lokeshwari, H., \& Chandrappa, G. T. (2006). Impact of heavy metals content in water, water hyacinth and sediments of Laibagh tank, Bangalore. Indian J. Environ. Sci. Eng., 48, 183-188. http://www.neeri.res.in/jesevo14803006.pdf

MacFarlane, G. R., \& Burchett, M. D. (2002). Toxicity, growth and accumulation relationships of copper, lead and zinc in the Gray Mangrove Avicennia marina (Forsk) Veirh. Marine Environ. Res., 54, 65-85. http://dx.doi.org/10.1016/S0141-1136(02)00095-8.

McAllister, J. J., Smith, B. J., Baptista, N. J. A., \& Simpson, J. K. (2005). Geochemical distribution and bioavailability of heavy metals and oxalate in street sediments from Rio de Janeiro, Brazil: A preliminary investigation. Environ. Geoch. Heal., 27, 429-441.

Mielke, H. W. (1994). Lead in New Orleans soils: new images of an urban environment. Environ. Geochem. Health, 16, 123-128.

Mueller, G. (1979). Schwermettale in den sedimenten des Rheins - Veraenderungen seit. Umschau, 79, 778-783.

Mull, E. J. (2005). Approaches toward sustainable urban solid waste management: Sahakaranagar Layout. Unpublished M.Sc. thesis, Int. Environ. Sci., Lund University, Lund, Sweden, p. 37.

Odero, D. R., Semu, E., \& Kamau, G. (2000). Assessment of cottage industries-derived heavy metal pollution of soil within Ngara and Gikomba area of Nairobi city, Kenya. Afri. J. Sci. Technol., 1, 52-62. 
Onyeagocha, A. C. (1980). Petrography and Depositional Environment of the Benin Formation. Nig. J. Min. Geol., 17, 147-151.

Pascual, B., Gold-Bouchot, G., Ceja-Moreno, V., \& del Ri'o-garci'a, M. (2004). Heavy metal and hydrocarbons in sediments from three lakes from san Miguel, Chiapas, Mexico. Bull. Environ. Contam. Toxicol., 73, 762-769.

Perira, E., Baptista-Nato, J. A., Smith, B. J., \& Mcallister, J. J. (2007). The contribution of heavy metal pollution derived from highway runoff to Guanabara Bay sediments-Rio de Janeiro? Brazil Annals Brazillian Acad. Sci., 79, 739-750.

Preda, M., \& Cox, M. E. (2002). Trace metal occurrence and distribution in sediments and mangroves, Pumicestone region, southeast Queenland, Australia. Environ. Int., 28, 433-449.

Rayment, G. E., \& Higginson, F. R. (1992). Australian Laboratory Handbook of soil and water chemical methods. Port Melbourne: Reed International books Australia P/L, trading as Inkata Press.

Saharawat, K. L. (1982). Simple modification of the Walkey-Black method for simultaneous determination of organic carbon and potentially mineralizable nitrogen in tropical rice soils. Plant and soils, 69, 73-77.

Sharma, R., \& Pervez, S. (2003). Enrichment and exposure of particulate lead in a traffic environment in India. Environ. Geochem. Health, 25, 297-306.

SPSS-16. (2009). Statistical Package for the Social Sciences. Chicago, USA: SPSS Inc.

Tahri, F., Benya, M., Bounakla, E. I., \& Bilal, J. J. (2005). Multivariate analysis of heavy metal in soils, sediments and water in the region of Meknes, Central morocco. Environ. Monitor. Asses., 102, 405-417.

Tijani, M. N., Jinno, K., \& Hiroshiro, Y. (2004). Environmental impact of heavy metal distribution in water and sediment of Ogunpa River, Ibadan area, southwestern Nigeria. J. Min. Geol., 40(1), 73-83.

Uma, K. O. (1989). Water resource of Owerri and its environs, Imo state, Nigeria. J. Min. Geol., 22(1-2), 57-64.

USEPA. (1996). Test methods for evaluating solid waste. Physical/Chemical Methods (3rd ed.). Method 3050B, Acid Digestion of Sediment, Sludges and soils, USEPA, Washington, DC, SW-846.

Yahaya, M. I., Mohammad, S., \& Abdullahi, B. K. (2009). Seasonal variation of heavy metal concentration in Abattoir dumpsite soil in Nigeria. J. Appl. Sci. and Envr. Mgt., 13(4), 9-13.

Yoshida, M., Ahmed, S., Nebil, S., \& Ahmed, G. (2002). Characterization of leachate from Henchir El Yahoidia close landfill. Water Waste Environ. Res., 1, 129-142.

Zonta, R., Zaggia, L., \& Argese, E. (1994). Heavy metal and grain-size distribution in estuarine shallow water sediments of the Cona Marsh, Venice Lagoon, Italy. Sci. Total Environ., 151, 19-28. http://dx.doi.org/10.1016/0048-9697(94)90482-0 